\title{
INTERNATIONAL PROJECT CONFERENCE FOCUSING ON SCHOOL INCLUSION TAKING PART AT SILESIAN UNIVERSITY IN OPAVA
}

\author{
Martin Kaleja
}

The International professional and scientific conference which was organized by Research Center for Social Inclusion of the Faculty of Public Policies in Opava on 11 April 2019, opened with greetings by the dean of the Faculty, prof. PhDr. Rudolf Žáček, Dr. The guests and colleagues were welcomed by vice-dean for study and social affairs Mgr. et Mgr. Marta Kolařiková, Ph.D. The presenter who announced the cultural performance by the children's choir DOMINO who were accompanied by their conductor PaedDr. Ivana Kleinová from the partner I. Hurník Elementary School in Opava, was the director of one of the partner schools of the project Mgr. Monika Jarošová.

The conference, entitled "Family, School and Friends: Towards a Quality Joint Education", which was one of the outputs of the development project implemented by a team of researchers mainly from the Faculty of Public Policies in Opava and was attended by professionals, workers and educational experts. Also present were experts from various relevant lines of profession, parents, students and the general public who are involved in school education. The joint meeting of the project implementers, educators and academics in the field took place in the historical building of the Faculty of Public Policies in Opava of the Silesian University in Opava. Conference languages were Czech, Polish and Slovak. The event was attended by 95 participants.

The international dimension of the conference consisted in the participation of foreign partners and allied institutions which not only participated in this event, but also contributed to the coordination and participation on the entire event. There were representatives of Polish universities, for example from Czestochowa, Warsaw, Opole, Katowice, Lodz and Szeczyn and representatives from universities in Slovakia - from Prešov, Bratislava, Ružomberok, Banska Bystrica. Domestic academic institutions were represented by Charles University, Masaryk University, Palacky University in Olomouc and Ostrava University. The issue of quality and inclusive education were also the interest of representatives of public administration and social policy, for example representatives from the Government Office, the civic association ROMEO, the office of Ombudsman, Czech School Inspectorate, Regional Office of the Moravian-Silesian Region, and representatives and the City of Ostrava, Opava and Bruntal. The important event was divided into two parts. The first part consisted of plenary lectures which made for some interesting contributions. The first lecture on "Mental Health as One of the Indicators of the Quality of Life of Pupils with Special Educational Needs in an Inclusive School" by prof. PaedDr. Miroslava Bartoňová, Ph.D. from Charles University. Next came a lecture by PhDr. Hana Slaná, Director of the Moravian-Silesian office of the Czech School 
Inspection named "Czech School Inspection - Selected Aspects of the Implementation of Joint Education". An interesting concept of inclusion was presented by Gwendolyn Albert, an expert consultant at tackling the issue at several world and national platforms, who is also active in the Romea association. The plenary part was concluded by the head of the Research Centre for Social Inclusion and the principal project implementer, doc. PhDr. et. PhDr. Martin Kaleja, Ph.D., who spoke on "Implementation of Project Plans, Goals and Problems on the Example of an Inclusive School-Oriented Project of the Silesian University in Opava".

The second part of the conference consisted of topical discussion blocks. In the first section, moderated by colleagues from the University of Ostrava, doc. Mgr. et Mgr. Alena Seberová, Ph.D. and Mgr. Tatána Göbelová, Ph.D., contributions were made which related to two topical aspects of inclusive pupil education: education of pupils and competence of teachers. The presented topics of inclusive education of pupils were primarily concerned with values, learning support, internet danger issues and the pupils' healthy way of life. The field of development of teaching competencies was represented by contributions concerning the possibilities of teaching staff mentoring and professional teacher training system. Each presented paper was followed by a discussion which was enriched by the participation of representatives of various institutions in the field of inclusive education and also, of course, by the opportunity to share experience on the Czech-Polish international level. The second section contributions, which were moderated by members of the Research Centre for Social Inclusion, prof. PhDr. Pavel Mühlpachr, Ph.D. and Ing. Eva Nyklová, focused on social issues, affecting the relations and relationships of children, pupils and teachers. The participants of this section discussed with passion, tackling current challenges not only in primary education, but also in the pre-graduate training of future pedagogical staff. The third section was moderated by prof. PaedDr. Miroslava Bartoňová, Ph.D., in tandem with prof. PhDr. Marie Vítková, Ph.D., who work at the Research Centre for Social Inclusion at the Silesian University in Opava. The section's topical focus was in current issues of education of pupils with special educational needs jointly with intact classmates in an inclusive class of a mainstream school. Inclusion was targeted at the topics of education, teaching and didactics. Individualisation and differentiation in the teaching process using adequate strategies, methods and forms were also born in mind. At the end of individual sections, discussions were held on the presented papers.

The implementation team and the conference evaluated the event even in its course as successful.

\section{Author}

doc. PhDr. et PhDr. Martin Kaleja, Ph.D.

Faculty of Public Policies in Opava, Silesian University in Opava

Research Centre for Social Inclusion

Bezručovo nám. 885/14, 74601 Opava, Czech Republic

martin.kaleja@fvp.slu.cz 